\title{
A WORDY DIGRESSION: THE GAME OF HIPE
}

\author{
PETER WINKLER \\ Madison, New Jersey
}

In Mathematical Mind-Benders, Peter Winkler. Wellesley, MA: A K Peters, 2007. Reprinted by permission of A K Peters, Ltd. (www.akpeters.com).

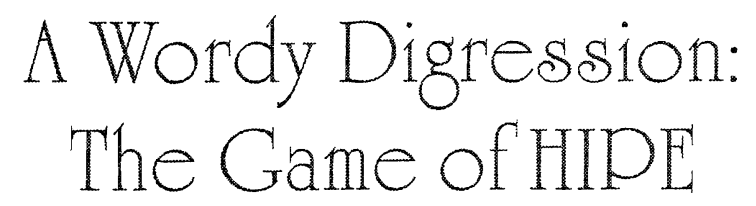

How every fool can play upon the word!

This is a free chapter-my publisher assures me that the book would be the same price without it. Think of it as an intermission, a non-mathematical break. Many mathematicians do love word games, though, and (in my experience) this one in particular.

You may have heard the following puzzle: what English word contains four consecutive letters that are consecutive letters of the alphabet? Answer: undeRSTUdy. Inspired by this and other word puzzles, I and three other high-school juniors ${ }^{6}$ at a 1963 National Science Foundation summer program began to fire letter combinations at one another, asking for a word containing that combination.

The combination had to appear in that order and with no other letters in between. Example: WKW = aWKWard, NSW = aNSWer. Some were only two letters, e.g., $\mathrm{HQ}=$ eartHQuake; $\mathrm{ZV}=$ rendeZVous (or another borrowed word, mitZVah). Try BV yourself (hint: this one is obvious).

Double letters (WW, VV, HH) can be fun too; but the most deadly combinations we found were three or four letters, as in GNT, PTC, THAC, HEMU - answers at the end of the chapter. We named the game after one of our favorite combinations, HIPE = arcHIPElago (despite later discovering that "worshiper" can be spelled with one "p"). Of course, HIPE has no doubt been invented and reinvented thousands of times over history, and you are under no obligation to use our name - but it's helpful to call it something.

In devising a HIPE, a natural objective is for it to be artfully concealed in the solution; and it's additionally satisfying for the solution to be a common

\footnotetext{
${ }^{6}$ Richard Thurston, Robert Webber, and Robert Winternitz-yes, roommates were assigned alphabetically.
} 
word that's hard to think of. For example, ONIG has a solution that is among the most common words in the language: can you find it? And what fun it is to stump a friend with a HIPE like LYLY, then tell them they have to add only one more letter.

Ideally, you'd like the solution to be unique (among, say, Scrabble ${ }^{\mathrm{TM}}$ eligible, non-capitalized words), but insisting on this leads to unnecessary quibbling. Still, a really good HIPE should have one standout answer. Back in 1963 we agreed on the following HIPE etiquette: when your victim produces a valid solution to your HIPE, his or her obligation is fully discharged. In particular, you are not allowed to ask for the solution you had in mind.

During the summers of 1967 and 1968 I gave a HIPE a day to all the (supposedly) gifted kids at Science and Arts Camps, in Port Ewen, NY. Here are some of their favorites: SPB, RAOR, XS, DQ, HCR, UDU, YEB, YNG, TIK, XOP, and BEK - answers at end of chapter.

Rarely do good HIPEs of more than four letters arise, since they tend to give away too much information. Two cute ones, notable for their pleasing repetitiveness, are ACHACH and TANTAN (solutions at end).

Who is good at solving HIPEs? Over the years, I have made an informal study of this question. Of course, as with mathematical puzzles, you never know until the game is played. People you think would be terrific fall flat on their faces, while others shock you by spouting answers you haven't even thought of.

There are some interesting tendencies, though. Once I found an excuse to introduce the game while teaching a class on automata about context-free languages; one student proved to be better at it than the rest of the class put together. She was the first educated person in her family and was a voracious reader who could spell many more words than she could pronounce. Naturally, she was less likely to be misled by tricky HIPEs; she knew words by their appearance.

How, indeed, do we "know" a word? Is it primarily by the word's meaning, by the word's sound, or by the word's appearance? Would you believe none of the above? My psychologist friends tell me that the kinetic sense of how to produce a word dominates, at least in some sense, the other aspects. Now, if that's really the case, then people who can't hear well, especially those who customarily communicate in a sign language, might be expected to have an advantage in playing HIPE. Their concept of a word might be expected to be short on sound and production (with the mouth) and thus relatively long on spelling. 
Resolved to test this hypothesis, I introduced HIPE to a group of hearingimpaired employees at a government agency, who sat together and conversed in ASL daily at lunch. They found the game completely trivial; as fast as I wrote HIPEs on napkins, they wrote solutions around them. To them it was a mystery why anyone would think HIPE was any kind of challenge.

Looking back on this episode, it occurs to me that the fact that some of the folks at this table were professional cryptanalysts should have made me a bit hesitant about drawing conclusions. But is the connection between hearing loss and code-breaking a coincidence? My advice is, if you need someone to (say) read a garbled telegram, try your hearing-impaired friends first.

Here's a longer list of HIPEs, with no solutions provided. Of course, you can find solutions for any of them easily on your computer, by downloading a word list from the web and searching for a given HIPE combination by your favorite method. But I suggest trying out your brain first.

$\begin{array}{llllll}\text { BG } & \text { CM } & \text { FC } & \text { FW } & \text { GC } & \text { GI } \\ \text { KC } & \text { GD } & \text { GZ } & \text { HK } & \text { IJ } & \text { KG } \\ \text { KJ } & \text { LJ } & \text { LQ } & \text { MD } & \text { MQ } & \text { PJ } \\ \text { TJ } & \text { TK } & \text { TV } & \text { UH } & \text { UQ } & \text { XF } \\ \text { XG } & \text { XN } & \text { XQ } & \text { ZB } & \text { ZK } & \text { ZM } \\ \text { ZP } & \text { ZW } & & & & \end{array}$

$\begin{array}{lllll}\text { AFY } & \text { AIE } & \text { AIQ } & \text { AKN } & \text { AKT } \\ \text { AMT } & \text { ANW } & \text { AOH } & \text { AOT } & \text { APK } \\ \text { ATG } & \text { AWG } & \text { BFR } & \text { BOF } & \text { BOI } \\ \text { BPL } & \text { BPO } & \text { BTF } & \text { CAQ } & \text { CEC } \\ \text { CEK } & \text { CHG } & \text { CTY } & \text { CYH } & \text { CYO } \\ \text { CZE } & \text { DDB } & \text { DDM } & \text { DEK } & \text { DEQ } \\ \text { DHP } & \text { DSC } & \text { DSK } & \text { DTE } & \text { DWR } \\ \text { DYB } & \text { DYG } & \text { DYM } & \text { EGW } & \text { EKD } \\ \text { EOI } & \text { ETD } & \text { EWG } & \text { EZA } & \text { FEG } \\ \text { FEK } & \text { FSA } & \text { FSI } & \text { FTB } & \text { FTT } \\ \text { GEC } & \text { GEF } & \text { GGN } & \text { GGP } & \text { GHG } \\ \text { GNP } & \text { GOC } & \text { GSK } & \text { HDI } & \text { HDU } \\ \text { HLR } & \text { HMM } & \text { HPL } & \text { HPR } & \text { HSH } \\ \text { HSK } & \text { HTC } & \text { HTG } & \text { HTM } & \text { HYN } \\ \text { IAI } & \text { IAU } & \text { IDP } & \text { IEI } & \text { IFA } \\ \text { IJI } & \text { IMF } & \text { IOA } & \text { IOE } & \text { IOI } \\ \text { IOV } & \text { IPK } & \text { IUT } & \text { LXF } & \text { IZU } \\ \text { KAC } & \text { KBL } & \text { KCL } & \text { KEB } & \text { KSG } \\ \text { KSK } & \text { KSU } & \text { KTR } & \text { KUS } & \text { KYC } \\ \text { KYR } & \text { LAL } & \text { LCL } & \text { LDB } & \text { LDT } \\ \text { LEK } & \text { LEQ } & \text { LFL } & \text { LIH } & \text { LKH } \\ \text { LML } & \text { LNO } & \text { LPF } & \text { LPL } & \text { LSC } \\ \text { LTC } & \text { LTP } & \text { LYD } & \text { LYF } & \text { LYV }\end{array}$


Mathermatical Mind-Benders

\begin{tabular}{|c|c|c|c|c|}
\hline MBB & $\mathrm{MBN}$ & MBP & MCH & MEU \\
\hline MKH & MND & MNL & MPF & MPG \\
\hline MPM & MPP & MSK & MSM & MSP \\
\hline MSU & MVE & MWI & NDD & NDJ \\
\hline NDK & NGN & NKG & NKM & NNK \\
\hline NYH & NYP & $\mathrm{OAB}$ & $\mathrm{OAU}$ & OAV \\
\hline OEQ & OEU & OHO & OHY & OIE \\
\hline OKC & OUA & OUQ & OWU & OYH \\
\hline OYO & OYR & PEV & PIF & PIU \\
\hline PFR & PPH & PSF & PSM & PSP \\
\hline PYC & PYW & RDP & RDV & RFD \\
\hline RUU & RLH & RMC & RMP & RNH \\
\hline RPM & RSB & RTG & RYD & SDR \\
\hline SHH & SIQ & SKR & SSK & SUO \\
\hline SYW & TBL & THC & THT & TIW \\
\hline TMU & $\mathrm{TOZ}$ & TYD & UAH & UDB \\
\hline UEO & UFA & UMC & UXU & VEF \\
\hline VEP & VEW & VYH & VYS & WAW \\
\hline WFE & WNC & WNM & WNP & WNU \\
\hline WSB & WSM & WSW & $\mathrm{XAD}$ & $\mathrm{XIB}$ \\
\hline XTB & XYE & XXM & XYS & YAG \\
\hline YFR & YHA & YOE & YRD & YSC \\
\hline YSL & YSY & YUN & $\mathbf{Y Z Y}$ & $\mathrm{ZEF}$ \\
\hline CEBE & DROB & & $\mathrm{ECIB}$ & ELEL \\
\hline ERYO & EWHA & & FELE & FRAR \\
\hline GHAG & GUAG & & FODI & HHOO \\
\hline HTEE & KADA & & LECU & LESL \\
\hline LSEL & IKEA & & ITCA & MECA \\
\hline MEON & NELT & & MYRO & NIKE \\
\hline OELA & OFOL & & OFTO & OOMM \\
\hline OORK & OMUC & & OWAD & OWNO \\
\hline PIOC & PLEL & & PONR & RESK \\
\hline ROOR & SPES & & TXPU & UBBD \\
\hline UGUG & ZIPA & & & \\
\hline
\end{tabular}

Promised solutions to earlier HIPEs:

- gloWWorm, poWWow

- saVVy, reVVing

- hitcHHike, batHHouse

- sovereiGNTy

- bankruPTCy

- tooTHAChe

- chrysantHEMUm 
- raSPBerry

- extRAORdinary

- coXSwain

- heaDQuarters

- witcHCRaft

- fraUdulent

- eYEBrow, eYEBall

- larYNGitis

- swasTIKa, baTIK

- saXOPhone

- unBEKnown

- stomACHACHe

- insTANTANeous

I hope you've enjoyed $\mathrm{HIPE}^{7}$ and will use the game to drive your friends crazy. Now back to mathematical puzzles.

\footnotetext{
${ }^{7}$ For those who think games like this are good for nothing, picture your author as a high-school senior trying to get into Haryard. He is asked to write about himself. He is from Fair Lawn, NJ, and is good at math. He is competing with kids who were raised by monks in Mandalay, played solo bassoon for the Queen of England, and cloned a moose at age 12. What can he say? Hoping to sucker the admissions officers into playing HIPE, he writes a light essay called "The HIPE Story" in which he describes how he and his friends started a local craze. Four years later, he is a senior at Harvard and overhears a tutor who had served on the admissions committee torturing a colleague with HIPEs. What's more, the tutor is calling them HIPES.

So, I figure HIPEs got me into Harvard, and I owe them this chapter.
} 